\title{
Separarion and Identification the Speciation of the Phenolic Compounds in Fruits and Leaves of Some Medicinal Plants (Juniperus phoenicea and Quercus coccifera) Growing at Al-Gabal Al-Akhder Region (LIBYA).
}

\author{
Hamad Mohammed Adress Hasan' \& Aisha Mohammed Rahil Ali² \\ ${ }^{1}$ Chemistry Department, Omar EI - Mukhtar University, LIBYA \\ ${ }^{2}$ Botany Department, Omar El - Mukhtar University, LIBYA
}

\begin{abstract}
The contents of the phenolic compounds can be summarizing as following :Juniperus phoenicea leaves :4,5-Dicaffeoly guinic acid $(0.003047 \mathrm{mg} / \mathrm{g})$, Cinnamic acid $(0.00000696 \mathrm{mg} / \mathrm{g})$, Galic acid $(0.0161 \mathrm{mg} / \mathrm{g})$ Geraniol $(0.000644 \mathrm{mg} / \mathrm{g})$, Phloridzin $(0.00000297 \mathrm{mg} / \mathrm{g})$, Quercetin $(0.02033 \mathrm{mg} / \mathrm{g})$ and Catecin $(0.0424 \mathrm{mg} / \mathrm{g})$. On the other side in Juniperus phoenicea fruits: 3,4-Dicaffeoly guinic acid $(0.00115 \mathrm{mg} / \mathrm{g})$, Galic acid $(0.0000975 \mathrm{mg} / \mathrm{g}$ and Catecin $(0.0424 \mathrm{mg} / \mathrm{g})$. While in Quercus coccifera plan : The concentrations were fluctuated as following: Quercus coccifera leaves: Chlorogeneic acid $(0.0115 \mathrm{mg} / \mathrm{g}), 3,4$ - Dicaffeoly guinic acid $(0.129 \mathrm{mg} / \mathrm{g}), 3,5$-Dicaffeoly guinic acid $(0.309 \mathrm{mg} / \mathrm{g}), 4,5$ - Dicaffeoly guinic acid $(0.0161 \mathrm{mg} / \mathrm{g}), 2,5$-dihydroxy Benzoic acid $(0.0000589 \mathrm{mg} / \mathrm{g})$, and Galic acid $(0.166 \mathrm{mg} / \mathrm{g})$. While in Quercus coccifera fruits the contents were recorded as following: $(0.0197 \mathrm{mg} / \mathrm{g}),(0.102 \mathrm{mg} / \mathrm{g}),(0.132 \mathrm{mg} / \mathrm{g})$, $(0.205 \mathrm{mg} / \mathrm{g})$, and cinnamic acid $(0.000698 \mathrm{mg} / \mathrm{g}$.
\end{abstract}

Keywords: Medicine plants, Phenolic compounds, Libya.

\section{INTRODUCTION}

\section{Medicinal plants in Libya}

North Africa includes Algeria, Egypt, Libya, Morocco, Mauritania and Tunisia The region consists of the biota of semi-closed Mediterranean and Red seas, with diverse ecosystems constituting About 10,000 vascular plant species. It has arid, Semi-arid and a range of sub-climatic zones. The Mediterranean basin is one of the 25 internationally recognized biodiversity hot spots in the world and it has extraordinary plant diversity and species endemism. Morocco has the highest rate of species endemism in the regio.

About $70 \%$ of plant species found in the wild have medicinal, aromatic and other uses. Over $10 \%$ of these have the potential for commercial exploitation as a source of drugs and pharmaceuticals.

\section{Medicinal plant Resources}

In Libya there are about 1,825 vascular plant species, of which 134 are endemic. About 450 species are reported to be of medicinal value. Some important plant families are Apiaceae, Asteraceae, Lamiaceae, Poaceae, Fabaceae, Brassicaceae and Abiaceae. Medicinal plants are distributed all over the country especially in the Al-Jabel Al-Akhdar, Ghadames, Gharian, Awbari and Tarhona regions. (Rateeb et al) More than 100 species are extensively used by Bedouins and local people in folk medicine drinks, or chewed fresh or dry.
DOI: 10.5530/ijper.51.3s.34 Correspondence: Hamad M Adrss Hasan, Chemistry Department, Omar El - Mukhtar University, LIBYA

Contact: 00218911412113

E-mail: drhamadmhasan85@ yahoo.com 
They are used to cure dermal diseases, viral or bacterial infections, insect or animal bites, burns and sometimes to treat hair problems. These medicinal plants are very well documented in different floras (El-Gadi and Bshana). Many species of medicinal plants such as Cupressus sempervirens L., Pinus halepensis Mill., Juniperus phoenicea L., Quercus coccifera L., Asperula arvensis L., Tribulus longipetalus Viv., Veronica cymbalaria Bodard and Vablia dichotoma (Murray) Kuntze are threatened because of over-harvesting and diversion of forest land to agriculture (Al- Idrissi et al). There is an urgent need to initiate programmers for collection and conservation of endangered and rare plant species to save them from extinction as a result of heavy grazing, human use and drought hazards that occur with increasing frequency. The most famous medicinal plant of Libya is Silphium cyrenaicum (now extinct). It existed during Greek and Roman times (900 to 100 B.C.). It was used for the treatment of many illnesses and was so important to the economy that was sold by weight with silver or gold and it was depicted on coins (Rateeb et al). It has been reported that Silphium grew abundantly in Cyrenacia (Al-jabel Al- Akhdar region) but heavy exploitation led to its extinction hundreds years ago. Many scientists have suggested different species for Silphium, but their suggestions are questionable. The herbal medicines most in demand are chamomile, thyme and rosemary. Libya exports medicinal plants to Egypt. Trade is handled by the private sector. About $30 \%$ of the population relies on traditional medicine in Libya. The Ministry of Health is planning to establish herbal medicine clinics as well as good manufacturing practices in the production of herbal medicinal products, which are mostly imported from Italy and other European countries. There is a lack of information on formal trade of medicinal and aromatic plants in the northern east side of Libya. This study aimed to separation and determination the phnolic compound in two medicinal plants (Juniperus phoenicea and Quercus coccifera) collected from al -gabal al -akder region (Libya).

\section{MATERIALS AND METHODS}

\section{Sampling}

\section{Selection of medicinal plants for this study}

Four different plants samples were collected from Al-Gabel Al -Kadar Region during spring 2015 Season, the- Samples including:

(Juniperus phoenicea and Quercus coccifera)

\section{Samples preparation}

Leaves and fruits of every type of Plant were separated and washed with distilled water several times, then dried in open air for fifteen days.

\section{Taxonomical investigation:}

The samples were identified by herbarium samples kept in seliphium herbarium, Faculty of Science, Omar Al Mokhtar University LIBYA.

\section{The phenolic compounds analysis:}

5 gram of powdered extracted for 30 minutes with $20 \mathrm{ml}$ mixture of chloroform methanol (2:1) and filtered. The marc (remained powdered) re extracted three times as mentioned (chloroform/ methanol) Combine the extracts and washed with distilled water. The extracted layer was concentrated to residue. (Chaman and Jangaard). The analysis of the compounds were carried out by phenolic compounds were identified by using GC -Mass instrument in Faculty of Science, Alexandria University, Egypt.

\section{Phenolic acids content:}

The types and contents of Phenolic compounds of studied plants are shown:

Tables 1 and Figures $(1,2,3,4,5 \& 6)$, the results may be summarized as following:

\section{RESULTS AND DISSCUTION}

Juniperus phoenicea: The concentration of phenolic acids in leaves and fruits of Juniperus phoenicea as following: Juniperus phoenicea leaves: 4,5-Dicaffeoly guinic acid $(0.003047 \mathrm{mg} / \mathrm{g})$, Cinnamic acid $(0.00000696$ $\mathrm{mg} / \mathrm{g})$, Galic acid $(0.0161 \mathrm{mg} / \mathrm{g})$ Geraniol $(0.000644$ $\mathrm{mg} / \mathrm{g})$, Phloridzin $(0.00000297 \mathrm{mg} / \mathrm{g})$, Quercetin (0.02033 mg/g) and Catecin (0.0424 mg/g). Juniperus phoenicea fruits: 3,4-Dicaffeoly guinic acid $(0.00115$ $\mathrm{mg} / \mathrm{g})$, Galic acid (0.0000975 mg/g and Catecin (0.0424 $\mathrm{mg} / \mathrm{g})$. Quercus coccifera: The concentration of phenolic acids in leaves and fruits Quercus coccifera as following: Quercus cocciferaleaves: Chlorogeneicacid $(0.0115 \mathrm{mg} / \mathrm{g})$, 3,4-Dicaffeoly guinic acid $(0.129 \mathrm{mg} / \mathrm{g}), 3$,5-Dicaffeoly

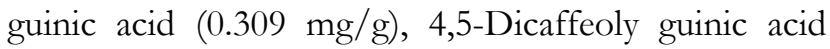
(0.0161 mg/g), (,2,5-dihydroxy Benzoic acid (0.00000589 $\mathrm{mg} / \mathrm{g})$, and Galic acid $(0.166 \mathrm{mg} / \mathrm{g})$. Quercus coccifera fruits: Chlorogeneic acid $(0.0197 \mathrm{mg} / \mathrm{g}), 3,4-$ Dicaffeoly

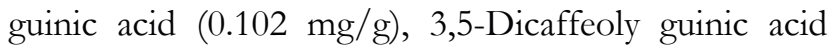
(0.132 mg/g), 4,5-Dicaffeoly guinic acid $(0.205 \mathrm{mg} / \mathrm{g})$, and cinnamic acid $(0.00000698 \mathrm{mg} / \mathrm{g})$. From the results which recorded in this study, the leaves containing different types of phenolic compounds comparing with the fruits. The caticen compound was recorded high content in Juniperus phoenicea leaves compared with 
Table 1: Phenolic compound contents in Juniperus phoenicea and Quercus coccifera (leaves and fruits)

\begin{tabular}{|c|c|c|c|c|}
\hline \multirow{2}{*}{ Phenolics $\mathrm{mg} / \mathrm{g}$} & \multicolumn{2}{|c|}{ J. phoenicea } & \multicolumn{2}{|c|}{ Q.coccifera } \\
\hline & leaves & fruits & leaves & Fruits \\
\hline Chlorogeneic aacid & - & - & 0.0115 & 0.0197 \\
\hline Caffeic acid & - & - & - & - \\
\hline 3,4-Dicaffeoly guinic acid & - & 0.00115 & 0.129 & 0.102 \\
\hline 3,5-Dicaffeoly guinic acid & - & - & 0.309 & 0.132 \\
\hline 4,5-Dicaffeoly guinic acid & 0.003047 & - & 0.0161 & 0.205 \\
\hline 2,5-dihydroxy Benzoic acid & - & - & 0.00000589 & - \\
\hline Cinnamic acid & 0.00000698 & - & - & 0.00000698 \\
\hline Galic acid & 0.0161 & 0.0000975 & 0.166 & - \\
\hline Geraniol & 0.000644 & - & - & - \\
\hline Tanic acid & - & - & - & - \\
\hline Phloridzin & 0.00000297 & - & - & - \\
\hline Quercetin & 0.02033 & - & - & - \\
\hline Catecin & 0.0424 & 0.0083 & - & - \\
\hline
\end{tabular}

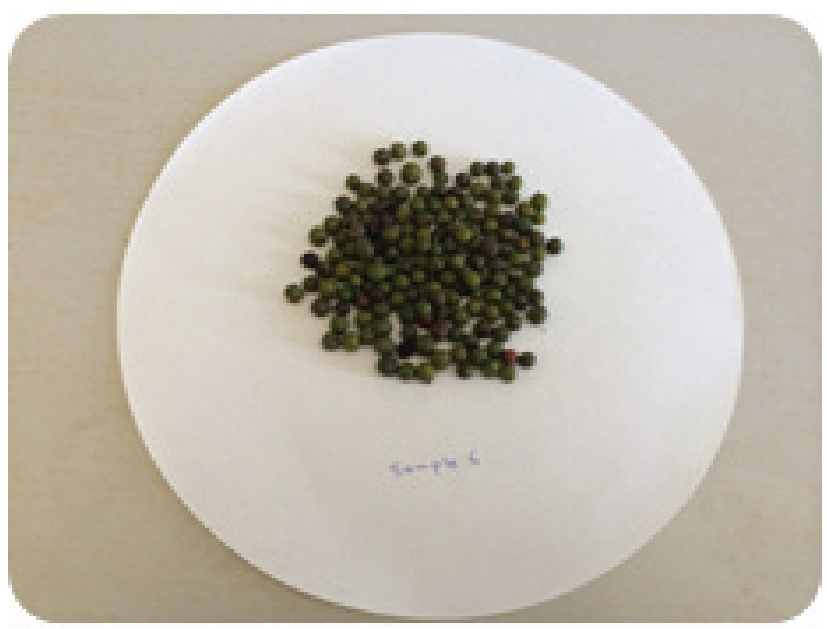

Figure 1:Juniperus phoenicea leaves

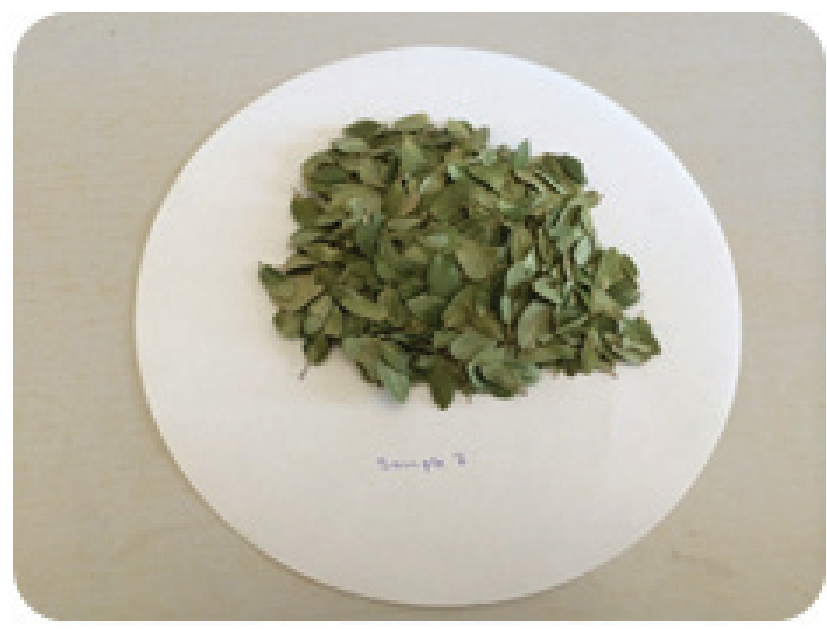

Figure 3: Quercus coccifera leaves

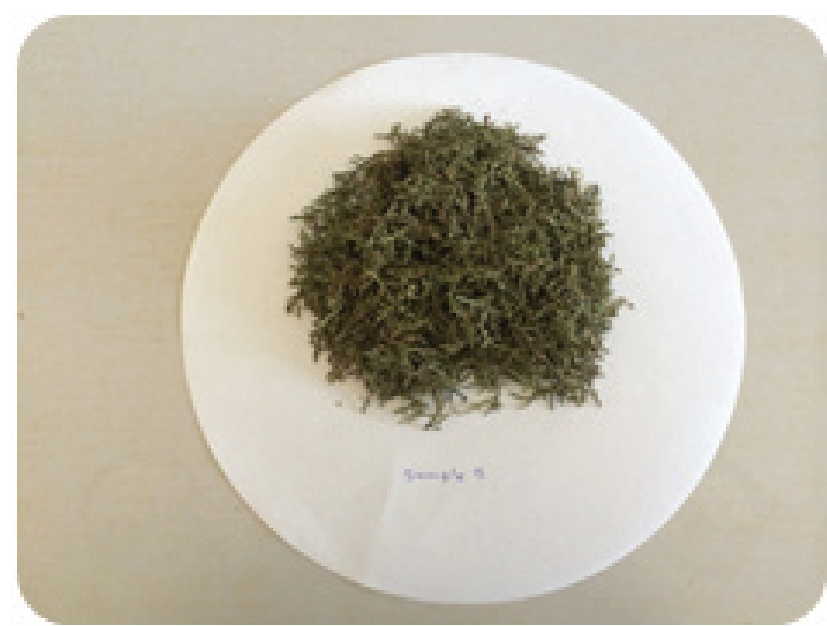

Figure 2: Juniperus phoenicea fruits

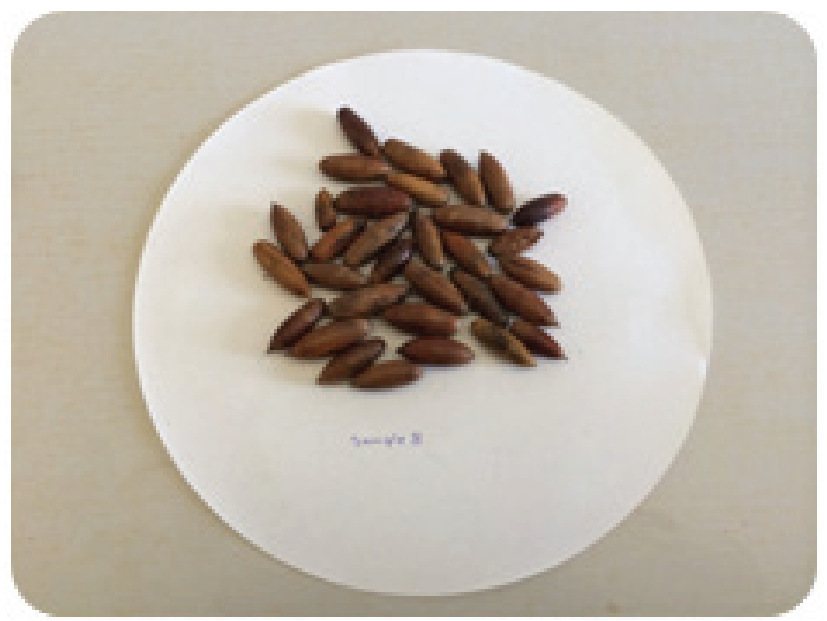

Figure 4: Quercus coccifera fruits 


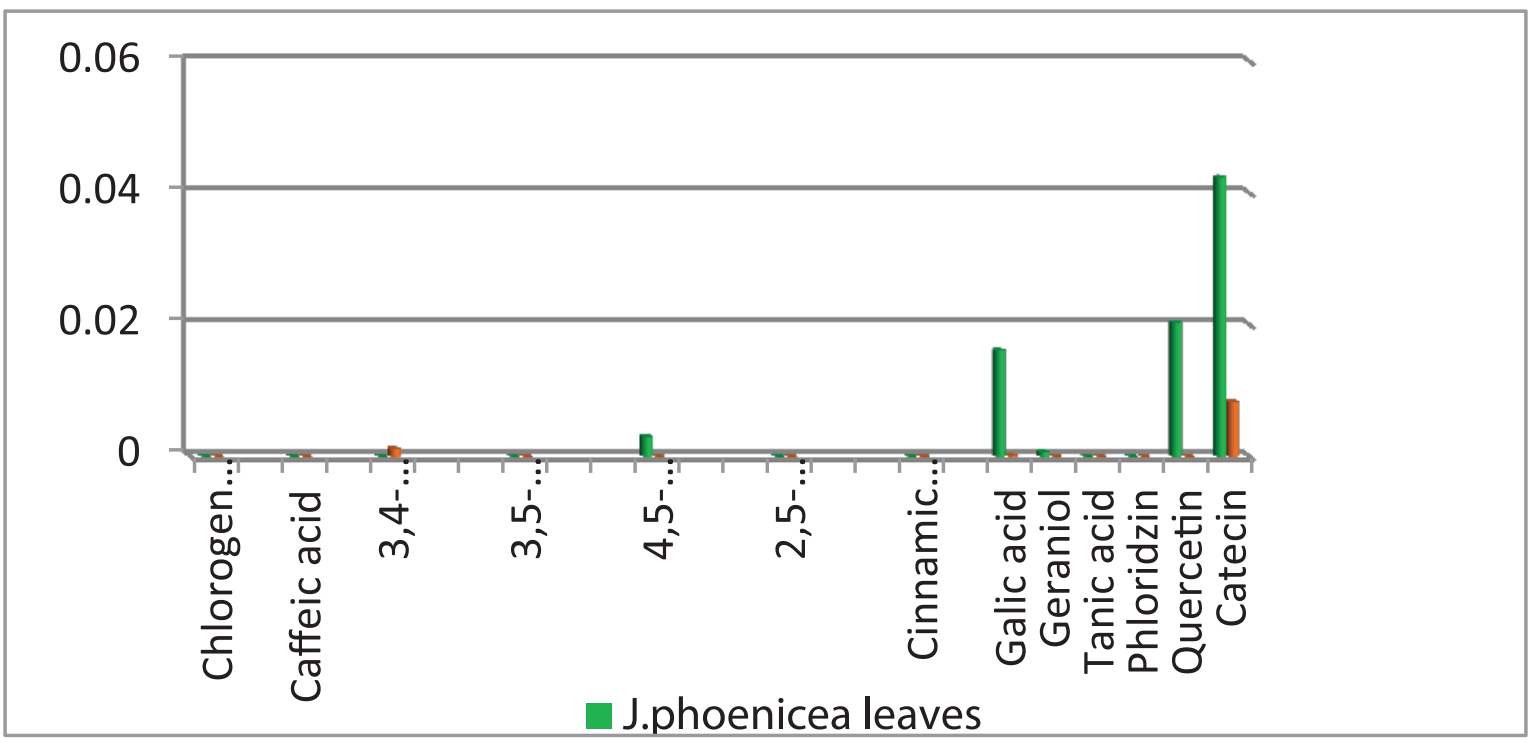

Figure 5: Phenolics content in Juniperus phoenicea leaves and fruits.

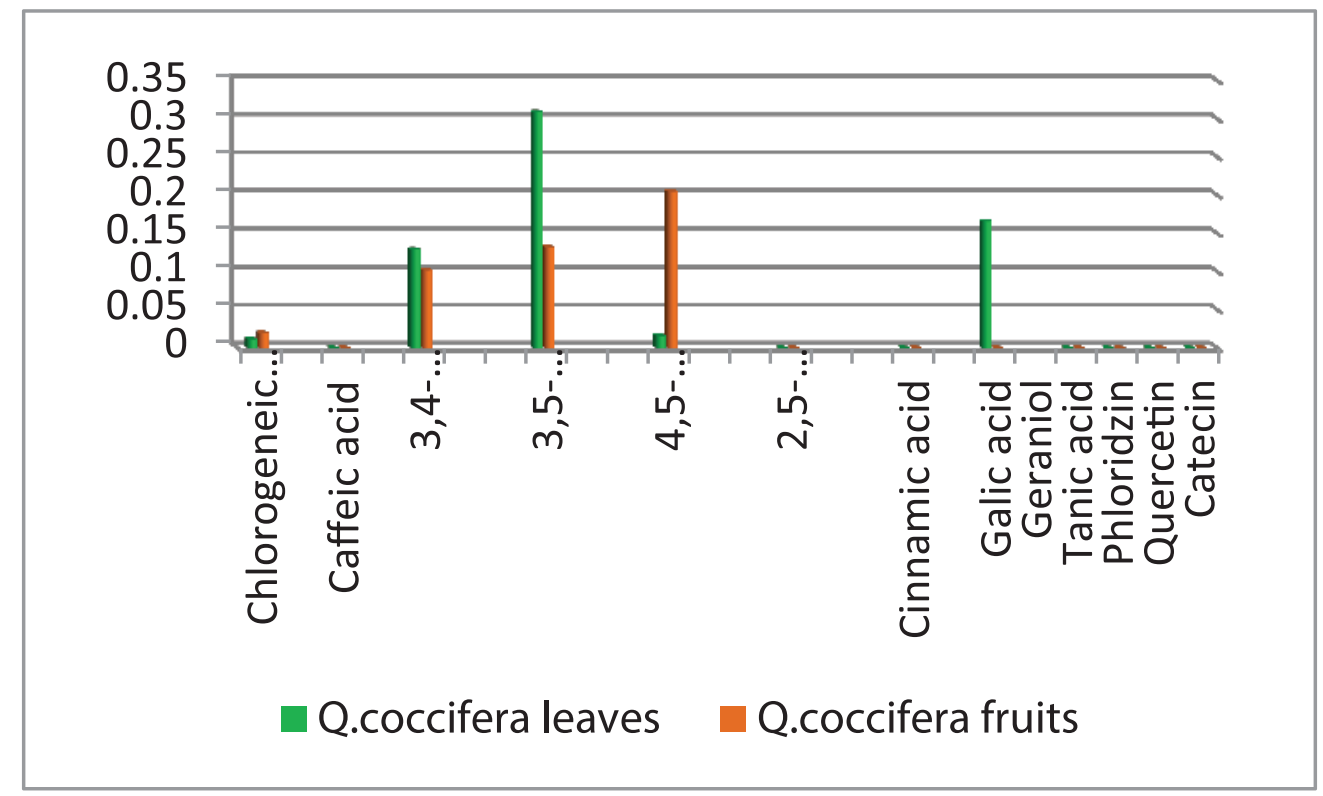

Figure 6: Phenolics content in Quercus coccifera leaves and fruits.

the other compounds. On the side the 3,5-Dicaffeoly guinic acid recorded high content in Quercus coccifera leaves. Also the results showed that the leaves of Quercus coccifera compared with Juniperus phoenicea leaves. This study is mainly the first study which recorded the speciation of phenolic compounds of the plants under investigation, where no results were published on the two plants. But some studies which carried out on some Libyan plants recorded presence of phenolic compounds in many Libyan plants but without gave the types of them.

\section{CONCLUSION}

The studied plants recorded different types and contents of phenolic compounds in leaves and fruits, many of phenolic compounds were not recorded. The leaves containing important values comparing with fruits.

\section{ACKNOWLEDGEMENT}

The authors are highly thank the central lab of chemical analysis of omar El -Mukhtar University, LIBYA 


\section{CONFLICT OF INTEREST}

None

\section{REFERENCES}

1. Al-idrissi M, Sbeita A, Jebriel A, Zintani A, Shreidi A, Ghawawi H, et al. (1996): Country report to the FAO International Agency. 1996.

2. Badi AH. Commercialization of Medicinal and Aromatic Plants and Its Effect on the Depletion of Some Species of these Plants in Gebel Akhder. M.Sc. Thesis, the Academy of Post-Graduate Studies, Benghazi, Libya. 2006.

3. Chaman KG, Jangaard PM. Fractional distillation of herring oil methylesters. J Ass of Agric Chem. 1973;50(1):1-8.
4. El-Gadi A, Bshana S. Usage of some plants in Libyan folk medicine, Volume 1 \& 2, AUP Publication, Libya (in Arabic). 1992.

5. Hegazy AK. Intra-population variation in reproductive ecology and resource allocation of the rare biennial species Verbascum sinaiticum Benth in Egypt, Journal of Arid Environments. 2000;44:185-96

6. Rateeb F, Adurahaman F, Auzi A. IUCN programme for conservation and sustainable use of medicinal plants in Libya, Phase I. 1996.

7. Ucko PJ, Dimbleby GW. The domestication and exploitation of plants and animals, Gerald Duckworth \& Co. Ltd., London, UK. 1996.

8. UNESCO/UCO: Multipurpose Species in Arab African Countries, United Nations Educational, Scientific and Cultural Organization, Cairo, Egypt. 1998.

9. WCMC: Global biodiversity: status of the Earth's living resources, In Groombridge B. (Ed.), A Report by the World Conservation and Monitoring Centre, Chapman \& Hall, London, UK. 1992.

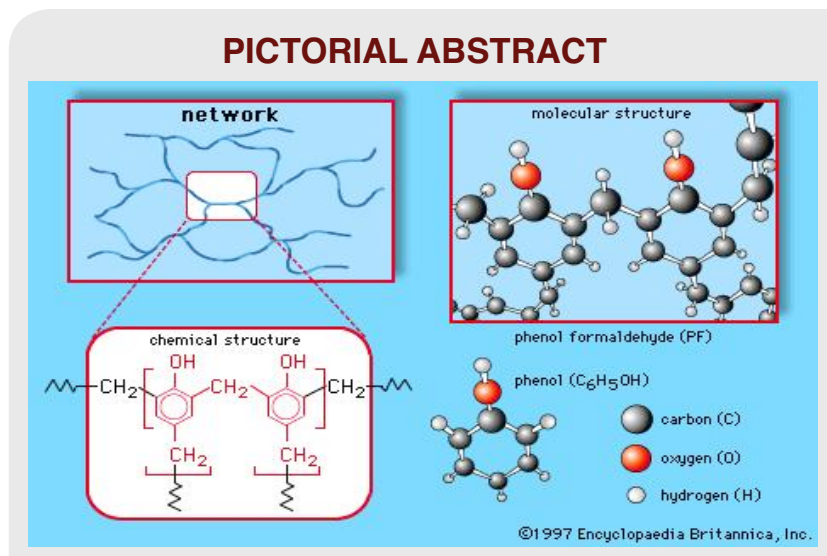

\section{SUMMARY}

- Phenolic compounds, Medicine plants

- The leaves contain high contents.

- The galic acid was recorded in most samples.

- The high content of the recorded was related to 3,5-Dicaffeoly guinic acid in Q.coccifera plant leaves.

\section{About Authors}

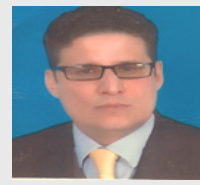

Prof. Dr. HAMAD M ADRESS HASAN: Professor of analytical chemistry, Omar El -Mukhtar Univeristy, LIBYA.

Dr. ASHIA MOHAMMED RAHIL ALI: Botany Department ,Omar El -Mukhtar University, Libya.

Cite this article: Hamad MAH \& Aisha MRA. Separarion and Identification the Speciation of the Phenolic Compounds in Fruits and Leaves of Some Medicinal Plants (Juniperus phoenicea and Quercus coccifera) Growing at Al -Gabal Al -Akhder Region (LIBYA). Indian J of Pharmaceutical Education and Research. 2017;51(3)Suppl:S299-303. 